\title{
STRATEGI PENGEMBANGAN DESA WISATA MENGGORO SEBAGAI WISATA HALAL
}

\author{
Yulfan Arif Nurohman, Rina Sari Qurniawati \\ Fakultas Ekonomi dan Bisnis Islam, IAIN Surakarta \\ ${ }^{1)}$ yulfanan@gmail.com \\ STIE AMA Salatiga \\ ${ }^{2)}$ rinasari.qurniawati@stieama.ac.id
}

\begin{abstract}
ABSTRAK
Parawisata mengalami keterpurukan sejak pandemi covid-19 masuk Indonesia. Kebijakan penutupan dan penghentian sementara segala aktivitas parawisata dilakukan oleh pemerintah untuk mengurangi penyebaran virus. Dampak kebijakan tersebut ialah penurunan pendapatan pengelola parawisata dan masyarakat yang terlibat langsung adanya keberadaan wisata. Saat ini berbagai upaya dilakukan untuk memulihkan kembali kondisi parawisata di Indonesia. Salah satu potensi yang dapat dipulihkan dan dikembangkan ialah Desa Wisata Menggoro. Penelitian ini bertujuan untuk menyusun strategi pengembangan Desa Wisata Menggoro menjadi wisata halal agar lebih menarik minat kunjungan wisatawan. Metode yang digunakan adalah diskriptif kualitatif dengan analisis SWOT. Pengumpulan data dilakukan dengan cara observasi langsung terhadap desa wisata dan wawancara dengan pengelola desa wisata serta masyarakat yang terlibat langsung dengan wisata Desa Menggoro. Hasil dari penelitian berupa strategi pengembangan desa wisata menjadi wisata halal dengan memenuhi unsur-unsur wisata halal. Adapun strategi utama yang dilakukan ialah memasukan Desa Menggoro kedalam peta wisata halal, membangun penginapan syariah, sertifikasi halal makanan khas, dan pembangunan galeri keunggunlan desa.
\end{abstract}

Kata kunci: Desa Wisata, Wisata Halal, Desa Menggoro

\section{PENDAHULUAN}

Pandemi covid-19 telah berlangsung lebih dari satu tahun sejak pertama kali ditemukan di Indonesia pada awal tahun 2020. Berbagai kebijakan pembatasan kegiatan masyarakat membuat tingkat kunjungan wisata sampai pada titik terendah. Berdasarkan data Badan Pusat Statistik (2021), terdapat penurunan jumlah wisatawan yang cukup signifikan, ini terjadi pada wisatawan lokal dan wisatawan mancanegara. Total kunjungan wisatawan mancanegara ke Indonesia pada tahun 2020 sebesar 4,02 juta kunjungan. Dibandingkan dengan tahun 2019, jumlah wisatawan mancanegara turun sebesar 75,03 persen. Kondisi parawisata yang tidak baik membuat keadaan ekonomi masyarakat menjadi lesu.

Presiden Indonesia memberikan arahan terkait pemulihan industri parawisata dan ekonomi kreatif. Arahan tersebut disampaikan oleh Menteri Pariwisata dan Ekonomi Kreatif (Menparekraf), meliputi kemudahan investasi oleh pengusaha terutama pada sektor parawisata dan ekonomi kreatif dan kebijakan sektor keuangan terutama yang berkaitan dengan fintech atau venture capital (Kumparan Bisnis, 2021). Pakar kreatif strategi pariwisata, Rahmad (2020) menyampaikan bahwa beberapa kebijakan yang disiapkan harus mampu menjangkau pelaku-pelaku industri pariwisata secara merata. 
Menurut panduan UNWTO, negara-negara yang selama ini menggantungkan pendapatan melalui sektor pariwisata harus mulai mengembangkan visi pariwisata berkelanjutan (sustainable tourism). Maksud dari pariwisata berkelanjutan ialah pariwisata yang memperhitungkan dampak ekonomi, sosial, dan lingkungan saat ini dan masa depan, memenuhi kebutuhan pengunjung, industri, lingkungan, dan masyarakat setempat.

Taufan Rahmad juga berpendapat bahwa pentingnya mengelola wisatawan lokal dengan menerapkan protokol kesehatan yang ketat serta desa wisata dapat menjadi opsi dari new normal destination. Desa wisata menjadi salah satu pendorong kunjungan wisata domestik dan non domestik (Wicaksono \& Nuvriasari, 2012). Keberadaan desa wisata juga berdampak positif terhadap usaha ekonomi kerakyatan yang ada disekitarnya (Leonardi dan Rosmadi, 2018). Sehingga UKM merupakan salah satu komponen penting bagi desa wisata, karena meningkatkan pendapatan masyarakat setempat (Danang \& Pujiastuti, 2015).

Desa Wisata Menggoro yang terletak di Kabupaten Temanggung Provinsi Jawa Tengah terkenal dengan Masjid Wali (Masjid Jami') dan tradisi jumat pahing. Desa wisata tersebut menjadi salah satu yang terdampak dengan adanya pandemi covid-19. Kebijakan pembatasan kegiatan masyarakat membuat tradisi jumat pahing yang selalu diadakan secara rutin menjadi terhenti. Pengelola dan masyarakat yang terkait dengan Desa Wisata Menggoro merasakan imbasnya, yaitu penurunan pendapatan masyarakat. Dampak lain dari pandemi covid-19 pada Desa Wisata Menggoro meliputi penurunan daya beli masyarakat desa, meningkatnya angka pengangguran, dan terhentinya aktivitas UMKM. Apabila permasalahan tersebut dibiarkan terlalu lama, maka dikhawatirkan akan menambahkan angka kemiskinan.

Keberadaan Desa Wisata Menggoro identik dengan wisata halal. Hal ini tidak lepas dari pengunjung yang datang ke Masjid Wali (Masjid Jami') ialah umat muslim. Dimana para pengunjung biasanya memiliki hajat khusus untuk datang dan melakukan peribadatan di masjid tersebut. Sekertaris Jenderal Asosiasi Travel Halal Indonesia (ATHIN), Cheriatna (2018) menyatakan, bahwa ciri sebuah wisata dapat dikatakan halal, bukan diukur dari tersedian makanan halal. Tetapi terdapat unsur yang harus dicapai untuk memenuhi standar kebutuhan kaum muslim saat berwisata. Adapun unsur yang harus sesuai dengan standar wisata halal meliputi makanan, tempat ibadah, dan waktu ibadah.

Pada tahun 2019, Indonesia bersama Malaysia menduduki peringkat pertama dalam Global Muslim Travel Index (GMTI) sebagai destinasi wisata halal terbaik dunia. Indonesia memiliki banyak potensi untuk mengembangkan wisata halal, salah satunya ialah Desa Wisata Menggoro. Pada desa ini memiliki Masjid Wali dan tradisi jumat pahing turun temurun yang bercirikan kearifan lokal. Peluang Desa Wisata Menggoro untuk dikembangkan menjadi wisata halal sangat terbuka lebar, apabila didukung dengan unsur-unsur yang memenuhi wisata halal. Menurut World Tourism Organization (WTO), konsumen wisata halal bukan hanya umat Muslim tetapi juga non Muslim yang ingin menikmati kearifan lokal. Dibutuhkan strategi yang tepat agar pengembangan wisata halal mampu memberikan dampak positif bagi pengelola desa wisata dan masyarakat Desa Menggoro. 


\section{LANDASAN TEORI}

\section{Analisis SWOT}

Manajemen strategis adalah proses berkelanjutan untuk menciptakan, menerapkan, dan mengevaluasi keputusan yang memungkinkan organisasi mencapai tujuannya. Salah satu proses manajemen strategis adalah analisis eksternal dan internal, yang juga disebut Analisis SWOT. Leigh (2009) menyatakan bahwa Analisis SWOT adalah pendekatan untuk mempertimbangkan berbagai penghambat dan penambah kinerja yang dihadapi organisasi baik di lingkungan internal maupun eksternal. Kekuatan adalah penambah kinerja yang diinginkan sementara kelemahan adalah penghambat kinerja yang diinginkan, dengan keduanya berada dalam kendali organisasi. Peluang adalah penambah dan ancaman adalah penghambat kinerja yang diinginkan, meskipun ini dianggap di luar kendali organisasi.

Gurel \& Merba, (2017) mengemukakan dengan melakukan analisis eksternal, organisasi mengidentifikasi ancaman dan peluang penting dalam lingkungan persaingannya. Analisis ini juga meneliti bagaimana persaingan di lingkungan ini kemungkinan akan berkembang dan implikasi apa yang dimiliki evolusi terhadap ancaman dan peluang yang dihadapi organisasi. Sementara analisis eksternal berfokus pada ancaman dan peluang lingkungan yang dihadapi organisasi, analisis internal membantu organisasi mengidentifikasi kekuatan dan kelemahan organisasinya. Ini juga membantu organisasi memahami sumber daya dan kapabilitas mana yang mungkin menjadi sumber keunggulan kompetitif dan mana yang cenderung menjadi sumber keunggulan tersebut. Berdasarkan Analisis SWOT, organisasi dapat memilih strategi yang tepat.

Analisis SWOT merupakan proses yang melibatkan empat bidang menjadi dua dimensi. Analisis ini memiliki empat komponen yaitu: 'Kekuatan', 'kelemahan', 'peluang', 'ancaman'. Kekuatan dan kelemahan adalah faktor internal dan atribut organisasi, peluang dan ancaman adalah faktor eksternal dan atribut lingkungan. Analisis SWOT biasanya dibuat dalam kotak empat kuadran yang memungkinkan ringkasan yang diatur menurut empat judul bagian.

Dalam Analisis SWOT, aspek kuat dan lemah suatu organisasi diidentifikasi dengan memeriksa unsur-unsur di lingkungannya sedangkan peluang dan ancaman lingkungan ditentukan dengan memeriksa unsur-unsur di luar lingkungannya. Dalam pengertian ini Analisis SWOT adalah alat perencanaan strategis yang digunakan untuk mengevaluasi kekuatan, kelemahan, peluang dan ancaman suatu organisasi. Ini memberikan informasi yang membantu dalam mencocokkan sumber daya dan kemampuan organisasi dengan lingkungan kompetitif di mana ia beroperasi.

Kekuatan dan peluang sangat membantu untuk mencapai tujuan organisasi. Mereka menguntungkan bagi organisasi. Kelemahan dan ancaman berbahaya bagi pencapaian tujuan organisasi. Mereka tidak menguntungkan bagi organisasi. Oleh karena itu, yang mendasari setiap pemilihan strategi yang berhasil adalah analisis kekuatan dan kelemahan internal organisasi yang ditimbulkan oleh lingkungan internal serta peluang dan ancaman yang ditimbulkan oleh lingkungan eksternal. Dengan kata lain, peran manajer adalah untuk mencoba 'menyesuaikan' analisis eksternalitas dan internalitas, untuk menyeimbangkan kekuatan dan kelemahan organisasi dalam kaitannya dengan peluang dan ancaman lingkungan. 


\section{Wisata Halal}

Islam mempunyai dampak pada semua aspek kehidupan sehari-hari umat Islam dan juga efektif dalam perspektif mereka terkait dengan pariwisata dan perjalanan. Istilah halal memiliki dampak signifikan pada keputusan perjalanan dan pariwisata terkait umat Islam (terutama untuk yang konservatif). Dalam beberapa tahun terakhir industri pariwisata di Indonesia mengalami peningkatan minat terhadap pariwisata halal. Battour \& Ismail (2016) mendefinisikan pariwisata halal sebagai setiap objek atau tindakan wisata yang diperbolehkan menurut ajaran Islam untuk digunakan atau dilakukan oleh umat Islam dalam industri pariwisata Definisi tersebut menganggap hukum Islam (syariah) sebagai dasar untuk memberikan produk dan layanan pariwisata kepada pelanggan sasaran yang terutama Muslim, seperti hotel Halal (hotel yang sesuai dengan syariah), Resor Halal, restoran Halal, dan perjalanan Halal. Definisi tersebut mengklaim bahwa lokasi aktivitas tidak terbatas pada dunia Muslim. Oleh karena itu, ini mencakup layanan dan produk yang dirancang untuk pelancong Muslim di negara Muslim dan nonMuslim.

Sementara itu Mohsin et al., (2016) menyatakan bahwa pariwisata halal mengacu pada penyediaan produk dan layanan pariwisata yang memenuhi kebutuhan wisatawan Muslim untuk memfasilitasi ibadah dan kebutuhan diet yang sesuai dengan ajaran Islam. Oleh karena itu, pariwisata halal adalah jenis pariwisata yang menganut nilai-nilai Islam, dan dalam pengertian itu perbandingan dapat dibuat dengan pertumbuhan praktik perbankan Islam di mana keduanya mengizinkan anggota agama untuk berhasil menjadi bagian dari dunia kontemporer dengan cara yang konsisten dengan nilai dan praktik mereka.

Pasar parwisata halal di Indonesia sangatlah besar. Selain mayoritas masyarakat mengatut agama Islam, tempat pariwisata yang menawarkan "kehalalalan" juga semakin banyak. Meskipun ada berbagai permasalahan yang telah diidentifikasi untuk pengembangan tujuan wisata halal, namun dengan skala pariwisata domestik yang signifikan dan potensi besar di antara pasar Muslim dan non-Muslim, pariwisata halal merupakan segmen wisata penting dengan potensi pertumbuhan yang besar. Pengembangan wisata halal menjadi penting karena manfaatnya tidak hanya dirasakan oleh wisatawan muslim. Wisata halal terbuka untuk semua orang termasuk non-Muslim.

Dalam pengembangan wisata halal, Undang-Undang Kementerian Pariwisata Nomor 2 Tahun 2014 tentang Pedoman Penyelenggaraan Usaha Hotel Syariah Pasal 1 yang mengacu pada prinsip-prinsip syariat Islam sebagaimana ditetapkan fatwa dan/atau disetujui oleh Majelis Ulama Indonesia (MUI) (Jaelani, 2017). Istilah tersebut mulai digunakan dalam industri perbankan syariah Indonesia sejak tahun 1992. Dari industri perbankan berkembang ke sektor lain, yaitu takaful, hotel syariah, dan wisata syariah.

\section{Desa Wisata}

Perkembangan pariwisata di Indonesia akhir-akhir ini masuk ke dalam sebuah tatanan yang baru dengan munculnya model pariwisata berbasis desa wisata. Desa Wisata muncul karena adanya keinginan untuk menerapkan pembangunan masyarakat yang berkelanjutan (Dewi et al., 2013). Dengan adanya sebuah desa wisata diharapkan tercipta suatu pembangunan pariwisata yang berkesinambungan tanpa merusak nilai budaya masyrakat setempat. Pengembangan desa wisata di Indonesia mulai muncul sekitar tahun 2017 saat dicanangkannya Visit Indonesia sebagai langkah pemerintah salam 
mempromosikan pariwisata baik bagi wisatawan lokal maupun manca negara (Prafitri \& Damayanti, 2016).

Desa wisata sendiri adalah sebagai kawasan pedesaan yang menawarkan keseluruhan suasana yang mencerminkan keaslian pedesaan, baik tata ruang, arsitektur bangunan, maupun pola kehidupan sosial budaya masyarakat, adat istiadat kehidupan sehari-hari (Suwantoro, 1997 dalam Amerta (2017). Selaini itu desa wisata mampu menyediakan komponen kebutuhan dasar wisatawan, seperti akomodasi, makanan dan minuman, souvenir dan atraksi wisata. Selain itu, Inskeep (1991) mendefinisikan desa wisata, di mana sekelompok kecil wisatawan tinggal di atau dekat desa tradisional, seringkali terpencil dan belajar tentang kehidupan desa dan lingkungan setempat. Dikatakannya, desa wisata sebagai pengembangan kawasan desa dengan memanfaatkan berbagai potensi dan kemampuan unsur-unsur yang ada pada masyarakat desa yang dijadikan sebagai atribut produk wisata, menjadi rangkaian kegiatan wisata yang terpadu.

Komponen-komponen yang terdapat dalam desa wisata menurut Dewi et al. (2013) yang pertama adalah akomodasi. Komponen akomodasi adalah Sebagian dari tempat tinggal penduduk setempat atau suatu unit yang berkembang sesuai dengan tempat tinggal penduduk. Komponen selanjutnya adalah atraksi dimana adanya keseluruhan kehidupan sehari-hari masyarakat setempat yang memungkinkan wisatawan untuk berinteraksi sebagai partisipan akhir. Atraksi yang dapat dilakukan misalnya kursus tari, kursus Bahasa dan melukis ataupun hal-hal lain yang lebih spesifik.

\section{METODE PENELITIAN}

Metode yang digunakan dalam penelitian ini adalah diskriptif kualitatif dengan analisis SWOT dipilih untuk menggali data serta merumuskan konsep pengembangan destinasi yang berbasis pada Desa Wisata Menggoro, Kecamatan Tembarak, Kabupaten Temanggung. Metode ini digunakan untuk mendapatkan gambaran deskriptif tentang fenomena yang diamati karena mampu menggali pemaknaan terhadap suatu fenomena secara lebih mendalam (Creswell, 1994). Penelitian diskriptif kualitatif hanyalah menguraikan tanggapan atas situasi maupun peristiwa sehingga tidak dilakukan uji hipotesis maupun penjelasan hubungan kausalitas.

Pengumpulan data dilakukan dengan cara observasi langsung terhadap desa wisata ini untuk memperoleh data diskriptif dengan didukung data dari narasumber untuk memberikan penilaian terhadap variabel-variabel pada objek yang diamati.

\section{HASIL DAN PEMBAHASAN}

\section{Analisa SWOT}

Dalam analisa SWOT melakukan identifikasi terhadap lingkungan internal dan eksternal. Desa Wisata Menggoro memiliki lingkungan yang terdiri dari internal dan eksternal yang dapat dikembangkan menjadi wisata halal. Faktor lingkungan internal terdiri dari kekuatan dan kelemahan, sedangkan lingkungan eksternal berkaitan dengan peluang dan ancaman.

\section{1) Identifikasi Potensi Lingkungan Internal}

Faktor internal Desa Wisata Menggoro yang termasuk dalam kekuatan terdiri dari:

(1) sejarah bangunan atau masjid, (2) peran pemerintah desa, (3) tradisi turun-temurun,

(4) keberadaan makam para kiai, (5) penetapan desa wisata, (6) pembangunan infrastruktur, (7) usia pengelola desa wisata, (8) makanan khas, (9) fasilitas pendukung, (10) image yang sudah terbentuk. 
Kelemahan dari Desa Wisata Menggoro terdiri dari: (1) penataan pedagang, (2) lahan parkir yang memadai, (3) pasar bersifat tradisional, (4) keterlibatan masyarakat dalam pengelolaan desa wisata, (5) pelayanan, (6) promosi, (7) sarana dan prasarana pendukung, (8) lokasi pedagang yang belum merata dan hanya terpusat dibeberapa wilayah, (9) produk cinderamata.

\section{2) Identifikasi Potensi Lingkungan Eksternal}

Faktor eksternal yang memengaruhi pengembangan Desa Wisata Menggoro menjadi wisata halal yang termasuk dalam peluang meliputi: (1) tren wisata lokal, (2) kerjasama sesama pengelola desa wisata, (3) dukungan pemerintah daerah, (4) alokasi dana desa, (5) dukungan pemerintah pusat dalam pengembangan desa wisata dan ekonomi kreatif, (6) kolaborasi dengan komunitas kesenian lokal, (7) hubungan dengan komunitas yang memiliki ketertarikan pada parawisata, (8) pertumbuhan penduduk, (9) kerjasama dengan produsen cinderamta, (10) pertumbuhan kawasan industri, (11) kerjasama dengan penyedia jasa transportasi online, (12) daya tarik wisata halal. Sedangkan ancaman pada pengembangan Desa Wisata Menggoro meliputi: (1) berdirinya tempat wisata baru, (2) perubahan cara pandang masyarakat, (3) masuknya budaya asing, (4) gangguan keamanan, (5) kebijakan dimasa pandemi.

\section{Strategi Pengembangan Desa Wisata Menggoro Menjadi Wisata Halal}

Setelah melakukan identifikasi potensi faktor internal dan eksternal pada Desa Wisata Menggoro, maka tahap berikutnya melakukan penilaian pada faktor tersebut melalui matriks Internal Factor Analysis Strategy (IFAS) yang terdiri dari kekuatan dan kelemahan, serta menentukan Eksternal Factor Analysis Strategy (EFAS) yang terdiri dari peluang dan ancaman. Penilaian yang dilakukan pada IFAS dan EFAS dengan memberikan bobot dan rating yang digunakan untuk mengetahui tingkatan faktor berdasarkan skor yang dihasilkan.

\section{1) Hasil Evaluasi Faktor Strategi Lingkungan Internal}

Dalam tahapan ini melakukan analisa pada faktor internal yang terdiri dari kekuatan dan kelemahan Desa Wisata Menggoro dalam mengembangkan strategi untuk menjadi wisata halal. Tahapan dimulai dengan melakukan obeservasi dan wawancara kepada pengelola desa wisata dan masyarakat Desa Menggoro. Kriteria yang dilakukan pada faktor kekuatan dan peluang dengan memberikan bobot mulai 0,0 (tidak penting) sampai 1,0 (paling penting). Pada kolom rating menggunakan skala 5, dimulai dari 1 (sangat buruk) sampai 5 (sangat bagus). Sedangkan skor merupakan hasil perkalian antara bobot dengan rating.

Berdasarkan Faktor Internal Strategi maka dapat diketahui kekuatan dan kelemahan dari Desa Wisata Menggoro. Adapun kekuatan (strengths) yang dimiliki oleh Desa Wisata Menggoro yang terdiri dari: 
Tabel 1 : Kekuatan Desa Wisata Menggoro

\begin{tabular}{|c|c|c|c|c|}
\hline \multicolumn{5}{|c|}{$\begin{array}{l}\text { IFAS } \\
\text { Kekuatan }\end{array}$} \\
\hline No. & Faktor & Bobot & Rating & Skor \\
\hline 1 & $\begin{array}{l}\text { Terdapat Masjid Wali atau Masjid Jami' Menggoro sudah } \\
\text { berdiri ratusan tahun }\end{array}$ & 0,100 & 5 & 0,500 \\
\hline 2 & $\begin{array}{l}\text { Kebijakan pemerintah desa dalam mengelola dan mendukung } \\
\text { program-program terkait Desa Wisata Menggoro }\end{array}$ & 0,080 & 5 & 0,400 \\
\hline 3 & $\begin{array}{l}\text { Terdapat tradisi jumat pahing yang sudah berlangsung turun } \\
\text { temurun }\end{array}$ & 0,090 & 4 & 0,360 \\
\hline 4 & $\begin{array}{l}\text { Terdapat makam Kiai Pahing yang sering didatangi pengunjung } \\
\text { untuk berziarah }\end{array}$ & 0,040 & 4 & 0,120 \\
\hline 5 & $\begin{array}{l}\text { Ditetapkan sebagai desa wisata oleh Bupati Temanggung sejak } \\
\text { tahun } 2016\end{array}$ & 0,045 & 5 & 0,225 \\
\hline 6 & $\begin{array}{l}\text { Pembangunan infrastruktur yang dilakukan oleh pemerintah } \\
\text { Desa Menggoro untuk memudahkan akses bagi pengunjung ke } \\
\text { beberapa lokasi wisata religi }\end{array}$ & 0,045 & 4 & 0,180 \\
\hline 7 & $\begin{array}{l}\text { Pengelola desa wisata rata-rata usia muda sehingga memiliki } \\
\text { semangat yang tinggi dalam melakukan promosi kepada } \\
\text { generasi muda }\end{array}$ & 0,040 & 3 & 0,120 \\
\hline 8 & $\begin{array}{l}\text { Terdapat makanan khas Desa Menggoro yang menjadi salah } \\
\text { satu unggulan Kabupaten Temanggung }\end{array}$ & 0,040 & 5 & 0,200 \\
\hline 9 & Kemudahan akses jalan menuju Desa Wisata Menggoro & 0,030 & 4 & 0,120 \\
\hline 10 & $\begin{array}{l}\text { Terdapat pasar desa yang berlangsung tiga hari dari lima hari } \\
\text { pasaran sehingga mendukung aktivitas ekonomi desa wisata }\end{array}$ & 0,030 & 4 & 0,120 \\
\hline 11 & Keunikan citra religi Desa Wisata Menggoro & 0,080 & 5 & 0,400 \\
\hline Jumlah & & & & 2,745 \\
\hline
\end{tabular}

Pada tabel 1 diketahui bahwa terdapat nilai-nilai yang berbeda dalam faktor internal strategi yang berupa kekuatan. Berdasarkan tabel 1 diketahui bahwa dalam faktor kekuatan yang memiliki bobot tertinggi sebesar 0,10 yaitu keberadaan Masjid Wali atau Masjid Jami' Menggoro. Faktor keberadaan Masjid Wali sangat berpengaruh dalam pengembangan Desa Wisata Menggoro. Hal ini dikarenakan Masjid Wali merupakan ikon Desa Menggoro yang sudah berlangsung lama. Citra yang terbentuk pada Desa Menggoro sebagai desa yang terdapat masjid buatan wali sudah melekat secara turun temurun dan berlangsung ratusan tahun, sehingga pengunjung yang datang ke Desa Menggoro memiliki alasan utama untuk datang ke Masjid Wali dibandingkan mendatangi tradisi jumat pahing dan wisata ziarah.

Disamping memiliki banyak kekuatan, Desa Wisata Menggoro juga memiliki sejumlah kelemahan (weaknesess). Adapun kelemahan Desa Wisata Menggoro antara lain sebagai berikut: 
Tabel 2 : Kelemahan Desa Wisata Menggoro

\begin{tabular}{|c|c|c|c|c|}
\hline \multicolumn{5}{|c|}{$\begin{array}{l}\text { IFAS } \\
\text { Kelemahan }\end{array}$} \\
\hline No. & Faktor & Bobot & Rating & Skor \\
\hline 1 & $\begin{array}{l}\text { Penataan pedagang dalam tradisi jumat pahing yang belum tertata } \\
\text { rapi sehingga membuat pengunjung berdesakan }\end{array}$ & 0,050 & 5 & 0,250 \\
\hline 2 & $\begin{array}{l}\text { Ketersediaan tempat parkir mobil yang luas sehingga sering } \\
\text { menyebabkan kemacetan saat berlangsung tradisi jumat pahing }\end{array}$ & 0,050 & 4 & 0,200 \\
\hline 3 & Pengelolaan pasar jumat pahing masih bersifat tradisional & 0,055 & 3 & 0,165 \\
\hline 4 & $\begin{array}{l}\text { Keterlibatan masyarakat dalam mengelola desa wisata terbatas } \\
\text { pada lingkungan sekitar lokasi wisata religi }\end{array}$ & 0,070 & 4 & 0,280 \\
\hline 5 & $\begin{array}{l}\text { Kesadaran dan pengetahuan masyarakat dalam memberikan } \\
\text { pelayanan kepada pengunjung wisata religi }\end{array}$ & 0,030 & 4 & 0,120 \\
\hline 6 & $\begin{array}{l}\text { Promosi secara online melalui platform media sosial belum } \\
\text { banyak dilakukan }\end{array}$ & 0,020 & 5 & 0,100 \\
\hline 7 & $\begin{array}{l}\text { Belum terdapat home stay atau penginapan bagi pengunjung desa } \\
\text { wisata }\end{array}$ & 0,035 & 5 & 0,175 \\
\hline 8 & $\begin{array}{l}\text { Penempatan pedagang pasar jumat pahing hanya terkonsentrasi } \\
\text { dibeberapa tempat saja, sehingga dampak ekonomi tidak } \\
\text { dirasakan secara merata }\end{array}$ & 0,060 & 5 & 0,300 \\
\hline 9 & $\begin{array}{l}\text { Belum memiliki cinderamata yang menunjukan ciri khusus Desa } \\
\text { Wisata Menggoro }\end{array}$ & 0,030 & 4 & 0,120 \\
\hline \multicolumn{2}{|c|}{ Jumlah } & & & 1,710 \\
\hline
\end{tabular}

Faktor kelemahan pada tabel 2 menunjukan bahwa faktor tertinggi merupakan peran keterlibatan masyarakat dalam mengelola Desa Wisata Menggoro dengan bobot sebesar 0,07. Keterlibatan masyarakat dalam mengelola Desa Wisata Menggoro terbatas pada masyarakat sekitar Masjid Wali, pengelola yang ditetapkan oleh pemerintah desa, dan pihak-pihak yang terlibat langsung dalam kegiatan tradisi jumat pahing seperti petugas parkir, petugas keamanan, dan pedagang. Keterlibatan masyarakat memiliki maksud peran masyarakat dalam menjaga keberlangsungan desa wisata seperti memberikan pelayanan, bersikap ramah tamah kepada pengunjung, ikut melakukan kegiatan promosi melalui word of mouth maupun electronic word of mouth, menjaga kebersihan, menjaga sarana dan prasana, dan rasa memiliki pada desa wisata. 


\section{2) Hasil Evaluasi Faktor Strategi Lingkungan Eksternal}

Berdasarkan Eksternal Factor Analysis Strategy (EFAS) maka peluang (opportunities) Desa Wisata Menggoro terdiri dari:

Tabel 3 : Peluang Desa Wisata Menggoro

\begin{tabular}{|c|c|c|c|c|}
\hline $\begin{array}{l}\text { EFAS } \\
\text { Peluang }\end{array}$ & & & & \\
\hline No. & Faktor & Bobot & Rating & Skor \\
\hline 1 & Peningkatan daya tarik tren wisata halal di Indonesia & 0,040 & 4 & 0,160 \\
\hline 2 & $\begin{array}{l}\text { Kerjasama antar pengelola desa wisata di Kabupaten } \\
\text { Temanggung untuk membangun ekosistem parawisata }\end{array}$ & 0,040 & 4 & 0,160 \\
\hline 3 & $\begin{array}{l}\text { Dukungan pemerintah daerah dengan memberikan pelatihan dan } \\
\text { studi banding kepada masyarakat yang aktif mengelola desa } \\
\text { wisata }\end{array}$ & 0,050 & 4 & 0,200 \\
\hline 4 & $\begin{array}{l}\text { Penggunaan dana desa untuk pembangunan sarana dan prasarana } \\
\text { sebagai penunjang desa wisata }\end{array}$ & 0,050 & 4 & 0,200 \\
\hline 5 & $\begin{array}{l}\text { Dukungan pemerintah pusat tentang pengembangan desa wisata } \\
\text { dan ekonomi kreatif }\end{array}$ & 0,040 & 4 & 0,160 \\
\hline 6 & $\begin{array}{l}\text { Kolaborasi dengan komunitas kesenian lokal dalam tradisi jumat } \\
\text { pahing }\end{array}$ & 0,055 & 3 & 0,165 \\
\hline 7 & $\begin{array}{l}\text { Menjalin hubungan dengan komunitas yang memiliki } \\
\text { ketertarikan pada parawisata }\end{array}$ & 0,050 & 4 & 0,200 \\
\hline 8 & Jumlah penduduk yang terus meningkat & 0,060 & 4 & 0,240 \\
\hline 9 & $\begin{array}{l}\text { Kerjasama pembuatan cinderamata dengan daerah lain yang } \\
\text { terkait wisata religi }\end{array}$ & 0,090 & 3 & 0,270 \\
\hline 10 & Berdirinya kawasan industri besar di Kabupaten Temanggung & 0,060 & 4 & 0,240 \\
\hline 11 & $\begin{array}{l}\text { Kerjasama dengan penyedia jasa transportasi online dalam } \\
\text { meningkatkan kemudahan akses penjualan makanan khas Desa } \\
\text { Menggoro dan mengurangi permasalahan ketersediaan parkir } \\
\text { mobil }\end{array}$ & 0,035 & 3 & 0,105 \\
\hline 12 & Tren wisata lokal yang berlangsung di Indonesia & 0,080 & 4 & 0,320 \\
\hline Jumlah & & & & 1,620 \\
\hline
\end{tabular}

Pada tabel 3 menunjukan bahwa peluang Desa Wisata Menggoro terdapat bobot tertinggi sebesar 0,055 yaitu kolaborasi dengan komunitas kesenian lokal dalam tradisi jumat pahing. Di Desa Wisata Menggoro belum terdapat kesenian lokal yang dapat dipertunjukan kepada pengunjung, sehingga hal tersebut dapat dilakukan dengan melakukan kerjasama dengan kesenian lokal dari daerah lain. Cara ini dilakukan agar meningkatkan daya tarik bagi pengunjung untuk datang ke Desa Wisata Menggoro terutama pada tradisi jumat pahing. Jumlah pengunjung yang banyak mampu meningkatkan pendapatan masyarakat Desa Menggoro yang terlibat secara langsung pada kegiatan tradisi jumat pahing.

Selain memiliki berbagai peluang, Desa Wisata Menggoro juga memiliki ancaman (threats). Adapun beberapa ancaman Desa Wisata Menggoro antara lain: 
Tabel 4 : Ancaman Desa Wisata Menggoro

\begin{tabular}{|c|c|c|c|c|}
\hline \multicolumn{5}{|c|}{$\begin{array}{l}\text { EFAS } \\
\text { Ancaman }\end{array}$} \\
\hline No. & Faktor & Bobot & Rating & Skor \\
\hline 1 & $\begin{array}{l}\text { Munculnya tempat wisata lokal dibeberapa daerah eks } \\
\text { Karesidenan Kedu }\end{array}$ & 0,060 & 4 & 0,240 \\
\hline 2 & Perubahan pola pikir dan selera masyarakat dalam parawisata & 0,060 & 4 & 0,240 \\
\hline 3 & Masuknya budaya asing yang melalui media elektronik & 0,060 & 4 & 0,240 \\
\hline 4 & $\begin{array}{l}\text { Gangguan keamanan kepada pengunjung tradisi jumat pahing } \\
\text { berupa kasus pencopetan, pencurian sepeda motor, dan tindakan } \\
\text { kejahatan lainnya }\end{array}$ & 0,120 & 3 & 0,360 \\
\hline 5 & Kebijakan pemerintah terkait penutupan wisata dimasa pandemi & 0,100 & 4 & 0,400 \\
\hline \multicolumn{2}{|r|}{ 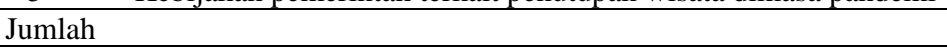 } & & & 1,480 \\
\hline \multicolumn{2}{|c|}{ Total Bobot Peluang + Ancaman } & 1,00 & & \\
\hline
\end{tabular}

Berdasarkan tabel 4, maka dapat diketahui bahwa ancaman pada Desa Wisata Menggoro terdapat bobot tertinggi sebesar 0,120 yaitu berkaitan dengan keamanan pada Desa Wisata Menggoro. Hal ini didasarkan atas seringnya kejadian pencopetan saat pengujung tradisi jumat pahing dengan jumlah banyak terutama saat Bulan Sura dan menjelang Bulan Ramadhan. Gangguan keamanan lain yang pernah dialami oleh pengunjung ialah kehilangan sepeda motor, meskipun hal ini terjadi karena pengunjung tidak parkir ditempat resmi yang telah disediakan oleh pengelola. Artinya pengunjung tersebut tidak memiliki karcis retribusi parkir karena tidak parkir ditempat yang disediakan oleh pengelola. Meskipun kejadian tersebut murni karena kesalahan pengunjung tidak parkir ditempat yang disediakan oleh pengelola, tetapi mengakibatkan berita negatif bahwa tingkat keamanan pada saat tradisi jumat pahing masih kurang. Sehingga hal ini dapat memengaruhi tingkat kunjungan pada Desa Wisata Menggoro.

\section{3) Analisa Matriks Internal-Eksternal}

Setelah menentukan penilaian pada Internal Factor Analysis Strategy (IFAS) yang terdiri dari kekuatan dan kelemahan, serta menentukan Eksternal Factor Analysis Strategy $(E F A S)$ yang terdiri dari peluang dan ancaman. Maka langkah berikutnya ialah menentukan strategi berdasarkan diagram analisa swot. Cara ini dilakukan dengan menghitung selisih total skor faktor internal dan faktor eksternal. Dari 11 indikator kekuatan dapat diidentifikasi dengan total skor sebesar 2,745. Sebanyak 9 indikator dari kelemahan diperoleh total skor sebesar 1,710. Hasil dari pengurangan faktor internal, yaitu kekuatan sebesar 2,745 dikurangi kelemahan 1,710 mendapatkan hasil 1,035.

Pada faktor eksternal terdiri dari 12 indikator peluang dengan total skor sebesar 1,620. Untuk aspek ancaman (threats) terdiri dari 5 indikator dengan total skor sebesar 1,480. Rata-rata faktor eksternal didapatkan dari selisih antara aspek peluang dan aspek ancaman adalah sebesar 0,140 . 


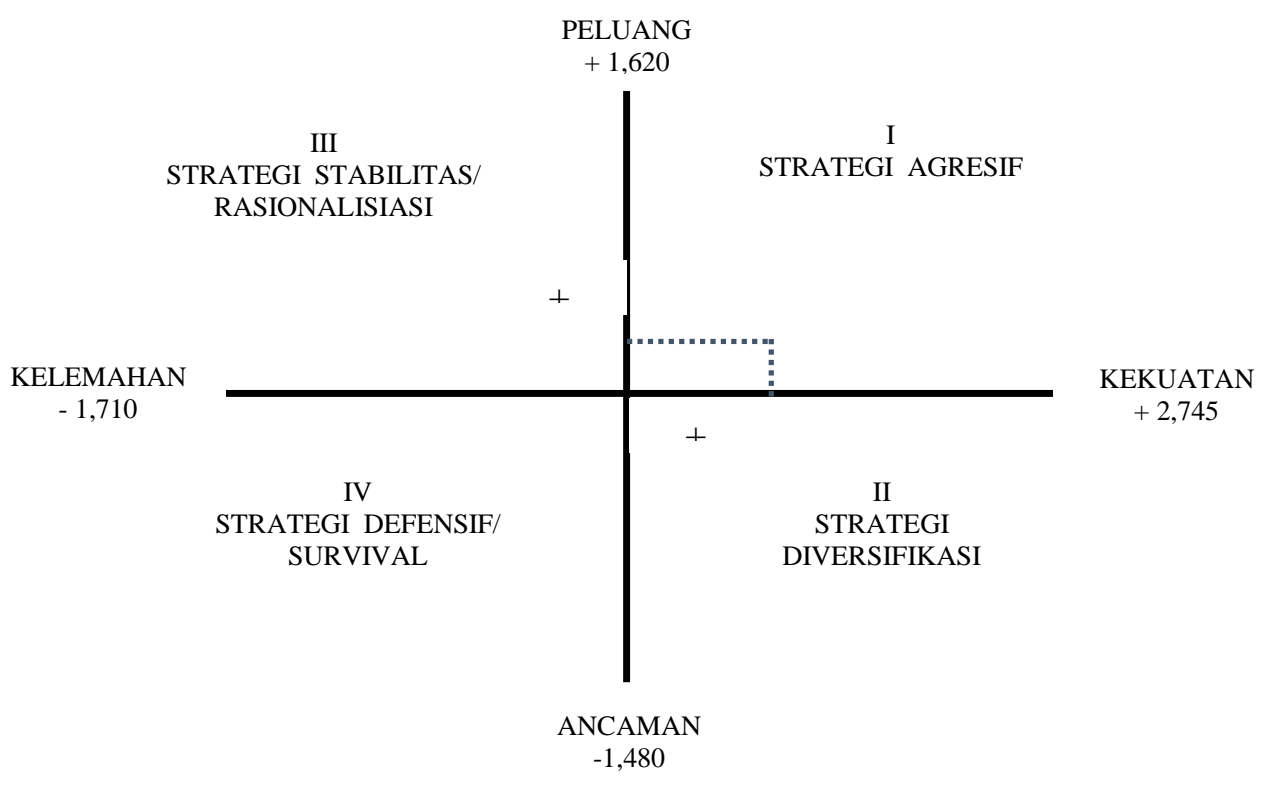

\section{Gambar 1. Diagram Analisa SWOT}

Berdasarkan gambar diagram Analisa SWOT, Desa Wisata Menggoro terletak pada kuadran I. Dimana kuadran I merupakan posisi sangat menguntungkan bagi Desa Wisata Menggoro dalam pengembangan wisata halal. Dimana strategi yang diterapkan mendukung kebijakan pertumbuhan yang agresif (growth oriented strategy). Strategi yang dilakukan ialah melakukan ekspansi untuk memenuhi standar wisata halal berkaitan dengan perwilayahan, daya tarik wisatawan, fasilitas umum, fasilitas pariwisata, aksesibilitas, dan investasi.

a) Memasukan Masjid Wali (Masjid Jami’ Menggoro) kedalam peta wisata halal yang didukung oleh pemerintah daerah.

b) Menyusun penginapan syariah dengan memanfaatkan rumah penduduk sebagai home stay dapat menunjang kelengkapan fasilitas parawisata. Dimana pada Desa Menggoro terdapat rumah-rumah berarsitektur kuno yang dapat menjadi keunggulan.

c) Pembuatan sentra makanan khas Desa Menggoro dan menyiapkan makanan khas untuk memiliki sertifikasi halal serta memiliki merek yang diakui secara legal.

d) Pembangunan galeri keunggulan Desa Menggoro yang dapat dimanfaatkan sebagai tempat pembuatan makanan khas dan memberikan kesempatan bagi pengunjung untuk terlibat langsung dalam pembuatan makanan khas.

\section{4) Strategi Alternatif Pengembangan Desa Wisata Menggoro}

Berdasarkan kondisi lingkungan internal dan eksternal Desa Menggoro, maka dilakukan analisa SWOT (Strenghts, Weaknesses, Opportunities, and Treaths) yang merupakan strategi alternatif pengembangan Desa Wisata Menggoro. Dalam matriks SWOT terdapat empat sel alternatif pengembangan desa wisata sesuai dengan kondisi lingkungan internal dan eksternal di Desa Menggoro. 
Tabel 5 : Analisis SWOT

\begin{tabular}{|c|c|}
\hline EFAS & Strenghts $(\mathrm{S})$ \\
\hline \multirow[t]{6}{*}{ Opportunities $(\mathrm{O})$} & $\begin{array}{c}\text { Strategi SO } \\
\end{array}$ \\
\hline & $\begin{array}{l}\text { 1. Menyelaraskan kebijakan } \\
\text { pemerintah Desa Menggoro terkait } \\
\text { program yang telah disusun dengan } \\
\text { kebijakan yang dilakukan oleh } \\
\text { pemerintah daerah (kabupaten) } \\
\text { maupun pusat dan memasukan } \\
\text { kriteria wisata halal sebagai unsur } \\
\text { utama }\end{array}$ \\
\hline & $\begin{array}{l}\text { 2. Penguatan branding wisata halal } \\
\text { dengan keunggulan citra yang sudah } \\
\text { terbentuk sebagai wisata religi } \\
\text { melalui event-event yang dilakukan } \\
\text { di Desa Menggoro }\end{array}$ \\
\hline & $\begin{array}{l}\text { 3. Mengadakan event kesenian } \\
\text { unggulan Kabupaten Temanggung } \\
\text { yang memenuhi kriteria wisata halal } \\
\text { pada saat pelaksanaan tradisi jumat } \\
\text { pahing }\end{array}$ \\
\hline & $\begin{array}{l}\text { 4. Mengoptimalkan peran pengelola } \\
\text { wisata yang berusia muda untuk } \\
\text { menjalin kerjasama dengan pihak- } \\
\text { pihak yang dapat mendukung desa } \\
\text { wisata, seperti kesenian daerah lain } \\
\text { yang memenuhi kriteria wisata halal }\end{array}$ \\
\hline & $\begin{array}{l}\text { 5. Melakukan kegiatan promosi } \\
\text { bekerjasama dengan komunitas } \\
\text { yang memiliki ketertarikan dengan } \\
\text { parawisata melalui media sosial }\end{array}$ \\
\hline
\end{tabular}

Threats (T)

Strategi ST
1. Bekerjasama dengan pengelola
wisata lain yang berada di
Kabupaten Temanggung untuk
mewujudkan ekosistem wisata
berkelanjutan dan kearifan lokal
dengan membuat peta wisata halal
yang dapat dikunjungi oleh
wisatawan dari satu daerah lanjut
kedaerah yang lain.
2. Mendaftarkan hak paten untuk
penamaan tradisi jumat pahing,
produk makanan khas Desa
Menggoro, dan produk lain yang
merupakan ciri khas Desa
Menggoro
3. Membentuk satgas khusus untuk
pengamanan dalam pelaksanaan
tradisi jumat pahing yang terbentuk
secara struktural dan disahkan oleh
pemerintah desa
4. Bekerjasama dengan pemerintah
kabupaten daerah untuk membuat
event produk unggulan Kabupaten
Temanggung

\section{Strategi WO}

1. Peningkatan sarana dan prasarana yang menunjang keberlangsungan wisata halal

2. Mendesain tempat tradisi jumat pahing menjadi modern dan tertata rapi sesuai dengan selera generasi muda dan kriteria wisata halal

3. Pendaftaran makanan khas Desa Menggoro agar bersertifikasi halal

4. Pembuatan outlet untuk produk-produk lokal Desa Menggoro, seperti cinderamata, makanan khas, dll

5. Memberikan pelatihan kepada pengelola desa wisata agar tercipta service excellent yang menjunjung nilai ke-Isalam-an

6. Bekerjasama dengan penyedia jasa transportasi online untuk memudahkan pengujung yang datang pada malam hari

\section{Strategi WT \\ 1. Membentuk sentra UMKM atau kelompok UMKM agar mudah dalam melakukan koordinasi dan pengembangan}

2. Memberikan bantuan pemasaran kepada pengusaha kuliner makanan khas Desa Menggoro agar tidak terbatas saat pelaksanaan tradisi jumat pahing

3. Memberikan pelatihan kepada generasi muda yang memiliki potensi kreativitas untuk membuat cinderamata Desa Wisata Menggoro sesuai dengan kriteria wisata halal

4. Bekerjasama dengan masyarakat lokal yang memiliki lahan luas atau para investor untuk membuat tempat parkir terintegrasi dengan desa wisata 


\section{PENUTUP}

Berdasarkan hasil analisis dan pembahasan SWOT dapat diambil kesimpulan bahwa untuk faktor internal kekuatan pengembangan Desa Wisata Menggoro adalah keberadaan ikon desa ini yaitu Masjid Jami' Menggoro. Sedangkan kelemahan yang ada adalah kurangnya partisipasi masyarakat dalam pengelolaan Desa Wisata ini. Berdasarkan analisis faktor eksternal peluang yang muncul adalah adanya kolaborasi dengan kesenian lokal yang dapat dipertunjukkan kepada pengunjung. Adanya banyak gangguan keamanan misalnya pencopetan merupakan ancaman yang dapat mempengaruhi tingkat kunjungan pada Desa Wisata Menggoro.

Setelah analisis SWOT dilakukan maka pemerintah Desa Menggoro dapat menjadikannya sebagai alat untuk mengambil kebijakan sebagai pengembangan wisata halal. Pemerintah Desa diharapkan dapat menggunakan kebijakan growth oriented strategy dengan memenuhi standar wisata halal terkait perwilayahan, daya tarik wisatawan, fasilitas umum, fasilitas pariwisata, aksesibilitas, dan investasi.

\section{DAFTAR PUSTAKA}

Amerta, I. M. S. (2017). The Role of Tourism Stakeholders at Jasri Tourism Village Development, Karangasem Regency. International Journal of Social Sciences and Humanities (IJSSH), 1(2), 20. https://doi.org/10.21744/ijssh.v1i2.32

Battour, M., \& Ismail, M. N. (2016). Halal tourism: Concepts, practises, challenges and future. Tourism Management Perspectives, 19, 150-154. https://doi.org/10.1016/j.tmp.2015.12.008

Cheriatna. (2018). Laris Manis Bisnis Wisata Halal. Gema Insani Press.

Creswell, J. W. (1994). Research Design: Qualitative and Quantitative Approache. Sage.

Danang, Y., \& Pujiastuti, E. E. (2015). UKM Sebagai Komponen Pengembangan Desa Wisata Yang Berkelanjutan. The 2nd University Research Coloquium 2015.

Dewi, M. H. U., Fandeli, C., \& Baiquni, M. (2013). Pengembangan desa wisata berbasis partisipasi masyarakat lokal di Desa Wisata Jatiluwih Tabanan, Bali. Jurnal Kawistara, 3(2).

GÜREL, E., \& Merba, T. (2017). SWOT Analysis: A Theoretical Review. Journal of International Social Research, 10(51), 994-1006. https://doi.org/10.17719/jisr.2017.1832

Jaelani, A. (2017). Halal tourism industry in Indonesia: Potential and prospects. International Review of Management and Marketing, 7(3).

Leigh, D. (2009). SWOT analysis. In Handbook of Improving Performance in the Workplace (pp. 115-140).

Mohsin, A., Ramli, N., \& Alkhulayfi, B. A. (2016). Halal tourism: Emerging opportunities. Tourism Management Perspectives, 19, 137-143. https://doi.org/10.1016/j.tmp.2015.12.010

Prafitri, G. R., \& Damayanti, M. (2016). Kapasitas Kelembagaan Dalam Pengembangan Desa Wisata (Studi Kasus: Desa Wisata Ketenger, Banyumas). Jurnal Pengembangan Kota, 4(1), 76. https://doi.org/10.14710/jpk.4.1.76-86

Rahmad, T. (2020). Bagaimana Sektor Pariwisata Indonesia Bertahan di Tengah 
Pandemi Corona. DW. https://www.dw.com/id/bagaimana-pariwisata-indonesiabertahan-di-tengah-pandemi/a-54818132

Wicaksono, G., \& Nuvriasari, A. (2012). Meningkatkan Kinerja Umkm Industri Kreatif Melalui Pengembangan Kewirausahaan Dan Orientasi Pasar: Kajian Pada Peran Serta Wirausaha Wanita Di Kecamatan Moyudan, Kabupaten Sleman, Propinsi DIY. Jurnal Sosiohumaniora, 3(4). 